\title{
Globally important refuge for the loggerhead sea turtle: Maio Island, Cabo Verde
}

\author{
Juan Patino-Martinez, Leno Dos Passos, Inês O. Afonso, Arnau Teixidor, \\ Manjula Timari, Tamás Székely and Rocío Moreno
}

\begin{abstract}
One of the largest nesting colonies of the Vulnerable loggerhead sea turtle Caretta caretta is in Cabo Verde. Here we present the first comprehensive study of loggerhead turtle nesting on the island of Maio in Cabo Verde. During 2016-2019 we monitored $38 \mathrm{~km}$ of undeveloped sandy beaches that have minimal artificial lighting and where all nesting on Maio takes place. We counted 4,063 nests in 2016, 5,429 in 2017, 14,364 in 2018 and 7,937 in 2019. The estimated total number of females was 1,016 , $1,357,3,591$ and 1,984 in each of these years, respectively. Our findings suggest there are more loggerhead turtles nesting in Cabo Verde than previously estimated, and that this could be the species' largest nesting subpopulation (followed by Florida, USA and Oman). The inter-annual hatching success (the proportion of eggs producing hatchlings) was $29-38 \%$ for the whole island but varied between sites. Our study of 250 clutches showed that flooding affected $38-61 \%$ and predation by crabs $40-42 \%$, with hatching success on different beaches in the range of $1-59 \%$. Poaching of eggs was rare ( $<2 \%$ of clutches), but dogs predated $68.4 \%$ of all clutches on the beach nearest the largest human settlement. We evaluated different nest management strategies at multiple sites and estimated productivity of hatchlings (the number of hatchlings that would reach the sea for each management strategy), finding that hatcheries are not always the best option for nest management. As the beaches on Maio are relatively undisturbed, and there is a high abundance and density of turtle nests, the island should be protected as a globally important site for the conservation of the loggerhead turtle, and of coastal biodiversity more broadly.
\end{abstract}

Keywords Cabo Verde, Caretta caretta, conservation management, conservation status, hatchery, hatching success, loggerhead sea turtle, nest management

Juan Patino-Martinez (Corresponding author, (1) orcid.org/0000-0002-71364616), Leno Dos Passos, Inês O. Afonso, Arnau Teixidor and Rocio Moreno Maio Biodiversity Foundation, Ilha do Maio, Cidade Porto Inglês, Cabo Verde E-mail juan.patino@fmb-maio.org

Manjula Tiwari Ocean Ecology Network, Research Affiliate to National Oceanic and Atmospheric Administration-National Marine Fisheries Service, Marine Turtle Ecology and Assessment Programme, South West Fisheries Science Center, San Diego, USA

TAmás Székely Department of Biology \& Biochemistry, Milner Centre for Evolution, University of Bath, Bath, UK

Received 11 June 2020. Revision requested 6 August 2020.

Accepted 14 October 2020. First published online 5 October 2021.

\section{Introduction}

T abitat alteration and destruction are major causes of 1 species extinction (Tilman et al., 1994). The seven species of sea turtle are threatened by development, artificial lighting and tourism on their nesting beaches (Sella \& Fuentes, 2019), and fisheries bycatch has resulted in drastic declines of some sea turtle populations (Santos et al., 2013; Hays et al., 2019). Additional threats are the harvest of eggs and adults on nesting beaches (McClenachan et al., 2006; Polasky, 2008), and anthropogenic pressure in the form of climate change, land transformation and pollution (Patino-Martinez et al., 2012; Patino-Martinez et al., 2017; Maxwell et al., 2019; Patrício et al., 2019; Sage, 2020). The decline of sea turtles has generated research and conservation interest from universities, government agencies, NGOs and the public (Hamann et al., 2010; Cornwell \& Campbell, 2012; Godley et al., 2020), but information on sea turtle populations that nest in relatively undisturbed areas is limited (Tomas et al., 2010; Mazaris et al., 2017).

The loggerhead sea turtle Caretta caretta nests in tropical and subtropical regions (Baldwin et al., 2003; Ehrhart et al., 2003). Population trends are variable, depending on the levels of threats and/or protection: some populations are increasing (Casale \& Matsuzawa, 2015) and others decreasing (Casale, 2015), and for some there are insufficient data (Nordberg et al., 2019). The largest known rookeries are in the north-west Atlantic in Florida, USA, and in Oman in the north-west Indian Ocean (Casale \& Tucker, 2017). The Republic of Cabo Verde in West Africa, an archipelago of 10 islands, has been considered the third largest loggerhead turtle nesting subpopulation (Casale \& Marco, 2015). The species is categorized as Vulnerable on the IUCN Red List, but with the north-east Atlantic nesting colony (nesting primarily in Cabo Verde) categorized as Endangered (Casale \& Marco, 2015). The latter has been identified as an isolated subpopulation, based on molecular studies (Monzon-Arguello et al., 2010; Stiebens et al., 2013), and is managed as a Regional Management Unit (Wallace et al., 2010).

In Cabo Verde the loggerhead turtle is threatened by high levels of anthropogenic development in nesting habitats (Loureiro, 2008; Abella Perez et al., 2016) and illegal capture for the meat trade and local consumption $(5-36 \%$ of nesting females per year; Marco et al., 2012; Dutra \& Koenen, 2014; Hancock et al., 2017). Additional threats are fisheries bycatch (Lewison et al., 2014; Coelho et al., 2015; Lopes et al., 2016; Bielli et al., 2019) and light pollution along the 
coast (Silva et al., 2017). It has been estimated that $75-85 \%$ of all nesting activity in Cabo Verde is on the island of Boa Vista (Marco et al., 2015; Tanner et al., 2019), where most research and monitoring efforts have focused since 2000 (López-Jurado et al., 2003; Hawkes et al., 2006; Monzon-Arguello et al., 2010; Camacho et al., 2013; Scott et al., 2014; Abella Perez et al., 2016; Usategui-Martín et al., 2019). Information about the abundance, trends and reproductive success of nesting females on other islands is limited (Taylor \& Cozens, 2010; Cozens et al., 2011; Dutra \& Koenen, 2014; Rocha et al., 2015; Laloë et al., 2019), but such data, particularly long time series, are critical for the conservation of this subpopulation (Wallace et al., 2010; Mazaris et al., 2017).

Here we present the first detailed study of loggerhead turtle nesting on Maio over 4 years, including abundance, spatial distribution of nesting, reproductive success and threats. We also evaluated hatchling productivity (the number of hatchlings that would reach the sea) under two nest management strategies that were implemented on beaches with low natural hatching success. Our findings will facilitate a status assessment of this subpopulation and inform management actions.

\section{Study area}

The $269 \mathrm{~km}^{2}$ island of Maio (Fig. 1 ) is one of the 10 islands in Cabo Verde, West Africa. Loggerhead turtles nest on $38 \mathrm{~km}$ of sandy beaches along its $110 \mathrm{~km}$ coastline. The highenergy, steep beaches of Maio are largely undeveloped, with near pristine habitat and little anthropogenic disturbance. The colour and grain size of the sand varies. Only one of the beaches (Beach Rotxa, $0.8 \mathrm{~km}$ long) is artificially illuminated (Fig. 1).

\section{Methods}

\section{Nesting activity}

The entire $38 \mathrm{~km}$ of sandy beaches were surveyed for nesting abundance by 44 fieldwork teams (2-4 people per team). Beaches were monitored daily for 110-130 nights per nesting season, during 20.00-6.00, for 4 consecutive years (20162019). The teams recorded locations of all nesting activities (clutches laid and aborted nesting attempts) observed overnight, using GPS devices, and erased all turtle tracks using wooden rakes. Any nesting activity not recorded during the night was mapped during a daily track count in the early morning. We calculated the proportion of nesting activities resulting in successful deposition of eggs (nesting success) and nest density per linear $\mathrm{km}$ of beach for each site.

\section{Hatching success}

We determined the geographical coordinates of 88 clutches in 2017 and 162 in 2018, marking their positions with wooden stakes. For each clutch we counted the number of eggs during oviposition and monitored the nest until hatching. We determined hatching success as the per cent of eggs producing hatchlings. We recorded visible impacts on nests such as beach erosion, tidal flooding, natural predation and illegal harvesting at seven sites during 2017 and 2018 (Fig. 1, Table 2).

\section{Nest management strategies}

To evaluate nest management strategies that can help mitigate natural or anthropogenic threats, we conducted a field experiment in two phases. The first phase, in 2017, included seven study sites (Fig. 1), with 182 clutches subjected to nest management (either hatchery or relocation) and 88 nests remaining in situ as controls. In the hatchery treatment, we transferred 103 clutches to seven experimental open beach hatcheries (enclosures surrounded by a $1 \mathrm{~m}$ high plastic mesh and wooden fence to avoid predators such as crabs and dogs; $7 \times 7 \mathrm{~m}$; on a $0^{\circ}$ slope, above the high tide line; one hatchery in each of the seven study areas; Fig. 1), with 11-15 nests per hatchery. In the relocation treatment, we moved 79 clutches (10-19 per site) to areas well beyond the high tide line, to avoid flooding of nests. Control nests were not manipulated but observed in their original locations. We buried all treatment clutches at a maximum depth of $45 \mathrm{~cm}$, in nest chambers with a horizontal diameter of $25 \mathrm{~cm}$, which corresponds to the dimensions of natural nests in this area. Whenever possible, we randomly selected three nests per night (or on consecutive nights) at each site, one for each treatment and the control, so that the incubation regime of the study groups coincided in time. We counted the eggs and determined the hatching success for each treatment and control nest at each site.

In the second phase, in 2018, based on our experience in 2017, we chose one of the following four strategies for the seven sites (414 nests studied; Fig. 1, Table 3): (1) leaving nests in situ (site 3), (2) relocation to a hatchery on the same beach (sites 2, 4, 5, 7), (3) relocation to an area beyond the flood line on the same beach (site 1), and (4) translocation to a hatchery on a different beach (site 6). We calculated mean hatching success for each strategy and used this to generate a theoretical estimate of the hatchling productivity:

$$
H_{\text {prod }}=N \times M_{e} \times \frac{H_{\mathrm{me}}}{100}
$$

where $H_{\text {prod }}$ is the hatchling productivity, $N$ the number of nests of each treatment, $M_{\mathrm{e}}$ the mean number of eggs per nest and $\mathrm{HS}_{\mathrm{me}}$ the mean hatching success of each management strategy. 

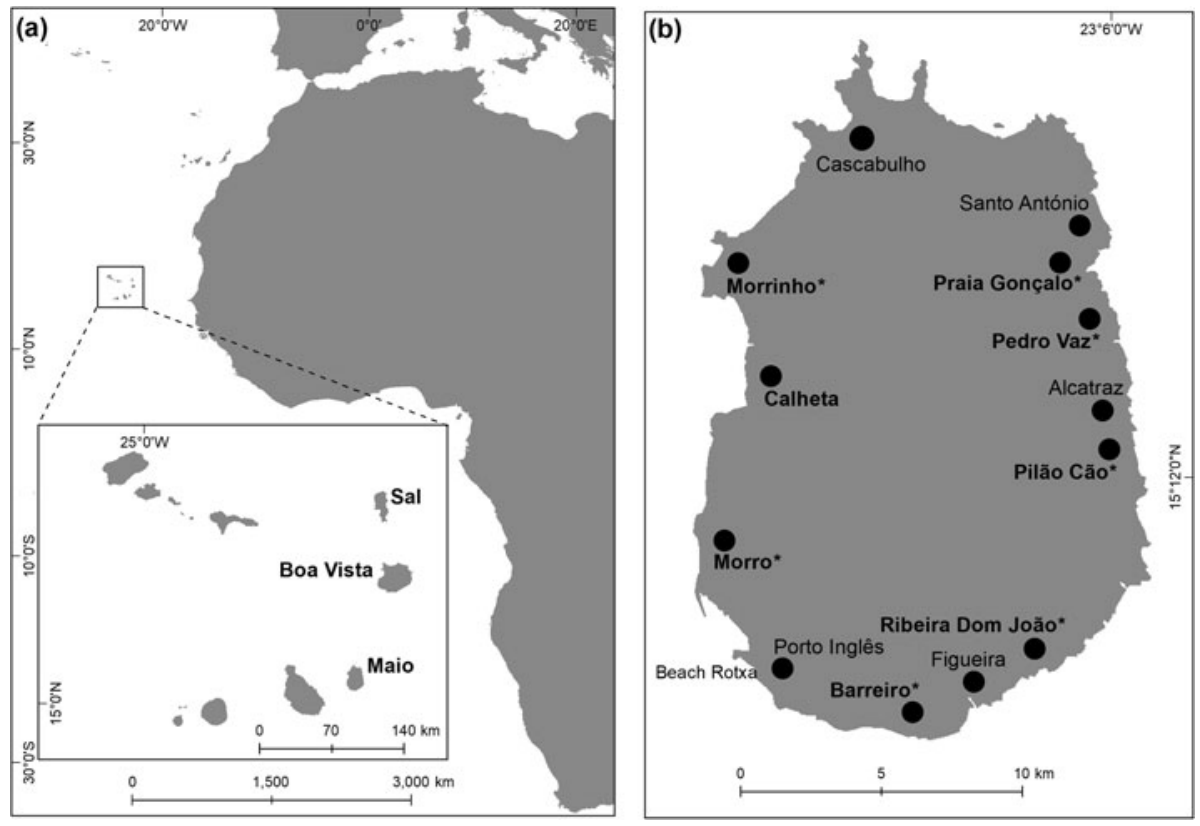

FIG. 1 (a) Location of the Cabo Verde archipelago off West Africa. (b) Maio Island, with 13 study camps that were established to monitor all of the island's loggerhead sea turtle Caretta caretta nesting beaches. The sites in bold are in Table 1 , and we examined clutch losses and effect of different nest management strategies at sites marked with * (Tables 2 \& 3).

Beach Rotxa is the only site with artificial illumination.

TABLE 1 Survey data of loggerhead sea turtle Caretta caretta nesting at the study sites (length of beach at each site in parentheses) on Maio Island, Cabo Verde during 2016-2019.

\begin{tabular}{|c|c|c|c|c|c|c|c|c|c|c|}
\hline Year & $\begin{array}{l}\text { Morrinho } \\
(6.1 \mathrm{~km})\end{array}$ & $\begin{array}{l}\text { Praia } \\
\text { Gonçalo } \\
(1.7 \mathrm{~km})\end{array}$ & $\begin{array}{l}\text { Pedro } \\
\text { Vaz } \\
(1.6 \mathrm{~km})\end{array}$ & $\begin{array}{l}\text { Pilão } \\
\text { Cão } \\
(1.1 \mathrm{~km})\end{array}$ & $\begin{array}{l}\text { Ribeira } \\
\text { Dom João } \\
(2.9 \mathrm{~km})\end{array}$ & $\begin{array}{l}\text { Barreiro } \\
(2.6 \mathrm{~km})\end{array}$ & $\begin{array}{l}\text { Morro } \\
(4.8 \mathrm{~km})\end{array}$ & $\begin{array}{l}\text { Calheta } \\
(3.5 \mathrm{~km})\end{array}$ & $\begin{array}{l}\text { Rest of the } \\
\text { island } \\
(13.7 \mathrm{~km})\end{array}$ & $\begin{array}{l}\text { Total } \\
(38.0 \mathrm{~km})\end{array}$ \\
\hline \multicolumn{11}{|c|}{ Total no. of nesting activities } \\
\hline 2016 & 649 & 1,113 & 952 & 1,800 & 1,613 & 2,228 & 878 & 348 & 1,404 & 10,985 \\
\hline 2017 & 697 & 2,030 & 1,353 & 2,594 & 1,691 & 1,518 & 826 & 600 & 1,497 & 12,806 \\
\hline 2018 & 1,607 & 4,167 & 4,402 & 4,070 & 2,801 & 3,148 & 3,447 & 1,131 & 5,302 & 30,075 \\
\hline 2019 & 646 & 3,294 & 3,026 & 2,695 & 2,689 & 2,167 & 1,672 & 532 & 2,595 & 19,316 \\
\hline \multicolumn{11}{|c|}{ Nesting success (\%) } \\
\hline 2016 & 45.5 & 48.6 & 47.7 & 47.3 & 21.9 & 24.0 & 41.9 & 42.5 & 36.8 & 37.0 \\
\hline 2017 & 47.1 & 61.7 & 41.5 & 44.6 & 20.2 & 28.2 & 42.6 & 47.7 & 48.4 & 42.4 \\
\hline 2018 & 56.9 & 65.0 & 45.7 & 59.6 & 30.8 & 36.4 & 40.7 & 61.5 & 41.4 & 47.8 \\
\hline 2019 & 48.8 & 48.1 & 41.9 & 57.1 & 23.9 & 25.7 & 39.7 & 52.3 & 41.8 & 41.1 \\
\hline \multicolumn{11}{|c|}{ Total no. of clutches } \\
\hline 2016 & 295 & 541 & 454 & 851 & 354 & 535 & 368 & 148 & 517 & 4,063 \\
\hline 2017 & 328 & 1,252 & 561 & 1,156 & 342 & 428 & 352 & 286 & 724 & 5,429 \\
\hline 2018 & 914 & 2,708 & 2,013 & 2,424 & 864 & 1,145 & 1,403 & 696 & 2,197 & 14,364 \\
\hline 2019 & 315 & 1,586 & 1,269 & 1,539 & 644 & 557 & 664 & 278 & 1,085 & 7,937 \\
\hline \multicolumn{11}{|c|}{ Density of nesting activities (per km) } \\
\hline 2016 & 107.2 & 663.7 & 606.0 & $1,569.3$ & 565.6 & 854.0 & 182.5 & 98.9 & 102.4 & 289.5 \\
\hline 2017 & 115.1 & $1,210.5$ & 861.2 & $2,261.6$ & 592.9 & 581.8 & 171.7 & 170.5 & 109.2 & 337.4 \\
\hline 2018 & 265.4 & $2,484.8$ & $2,802.0$ & $3,548.4$ & 982.1 & $1,206.6$ & 716.6 & 321.3 & 386.8 & 792.5 \\
\hline 2019 & 106.7 & $1,964.2$ & $1,926.2$ & $2,349.6$ & 942.8 & 830.6 & 347.6 & 151.1 & 189.3 & 509.0 \\
\hline \multicolumn{11}{|c|}{ Density of clutches (per km) } \\
\hline 2016 & 48.7 & 322.6 & 289.0 & 741.9 & 124.1 & 205.1 & 76.5 & 42.0 & 37.7 & 107.1 \\
\hline 2017 & 54.2 & 746.6 & 357.1 & $1,007.8$ & 119.9 & 164.0 & 73.2 & 81.3 & 52.8 & 143.1 \\
\hline 2018 & 150.9 & $1,614.8$ & $1,281.3$ & $2,113.3$ & 302.9 & 438.9 & 291.7 & 197.7 & 160.3 & 378.5 \\
\hline 2019 & 52.0 & 945.7 & 807.8 & $1,341.8$ & 225.8 & 213.5 & 138.0 & 79.0 & 79.1 & 209.1 \\
\hline
\end{tabular}

\section{Statistical analyses}

We used $R$ 3.5.2 (R Core Team, 2018) for statistical analyses. Normality and heteroscedasticity were tested using
Shapiro-Wilk and Levene's tests, respectively. We tested if nesting success and hatching success were significantly different between years and between sites using a one-way and a two-way ANOVA, respectively. If significant differences 
TABLE 2 Estimated loss and survival of clutches and hatching success at study the sites on Maio Island where we assessed reproductive success quantitatively, in 2017 and 2018.

\begin{tabular}{|c|c|c|c|c|c|c|c|c|}
\hline Year & Morrinho & Praia Gonçalo & Pedro Vaz & Pilão Cão & Ribeira Dom João & Barreiro & Morro & Weighted average \\
\hline \multicolumn{9}{|c|}{ Clutches flooded (\%) } \\
\hline 2017 & 20.0 & 8.3 & 37.5 & 60.9 & 64.7 & 66.7 & 22.2 & 37.8 \\
\hline 2018 & 47.1 & 36.4 & 92.5 & 84.6 & 67.9 & 64.3 & 26.3 & 61.2 \\
\hline \multicolumn{9}{|c|}{ Clutches eroded (\%) } \\
\hline 2017 & 20.0 & 8.3 & 0.0 & 0.0 & 11.8 & 0.0 & 22.2 & 6.5 \\
\hline 2018 & 11.8 & 13.6 & 30.0 & 19.2 & 3.6 & 14.3 & 5.3 & 15.8 \\
\hline \multicolumn{9}{|c|}{ Clutches harvested (\%) } \\
\hline 2017 & 0.0 & 0.0 & 0.0 & 4.8 & 6.5 & 0.0 & 0.0 & 1.7 \\
\hline 2018 & 3.0 & 0.0 & 0.0 & 0.0 & 7.1 & 7.1 & 0.0 & 1.5 \\
\hline \multicolumn{9}{|c|}{ Clutches predated (\%) } \\
\hline 2017 & 40.0 & 41.7 & 6.3 & 34.8 & 64.7 & 83.3 & 55.6 & 42.2 \\
\hline 2018 & 35.3 & 13.6 & 17.5 & 57.7 & 67.9 & 28.6 & 89.5 & 40.2 \\
\hline \multicolumn{9}{|c|}{ Clutch survival $^{1}(\%)\left(\mathbf{N}^{2}\right)$} \\
\hline 2017 & $60.0(5)$ & $66.7(12)$ & $93.8(16)$ & $73.9(23)$ & $23.5(17)$ & $50.0(6)$ & $22.2(9)$ & 63.0 \\
\hline 2018 & $76.5(17)$ & $72.7(22)$ & $73.0(37)$ & $76.9(26)$ & $22.2(27)$ & $71.4(14)$ & $5.3(17)$ & 61.8 \\
\hline \multicolumn{9}{|c|}{ Hatching success $(\%)\left(\mathrm{N}^{2}\right)$} \\
\hline 2017 & $37.9(5)$ & $41.3(12)$ & $59.0(16)$ & $19.8(23)$ & $5.1(17)$ & $0.8(6)$ & $16.6(9)$ & 29.0 \\
\hline 2018 & $56.3(17)$ & $43.6(22)$ & $43.2(37)$ & $48.6(26)$ & $7.7(27)$ & $39.0(14)$ & $4.4(19)$ & 37.6 \\
\hline
\end{tabular}

${ }^{1}$ Clutch survival is defined as at least one hatchling emerging from the clutch.

${ }^{2} \mathrm{~N}$, number of clutches assessed.

TABLE 3 Hatching success ( $\% \pm S D$, with number of nests in parentheses) for different nest management strategies, and recommended strategy for each site where we assessed reproductive success quantitatively.

\begin{tabular}{llllllll}
\hline & & & & \multicolumn{2}{l}{ Ribeira Dom } \\
& Morrinho & Praia Gonçalo & Pedro Vaz & Pilão Cão & João & Barreiro & Morro \\
\hline Natural nests & $37.9 \pm 48.2(5)$ & $41.3 \pm 38.2(12)$ & $59.0 \pm 31.0(16)$ & $19.8 \pm 23.0(23)$ & $5.1 \pm 16.4(17)$ & $0.8 \pm 1.6(6)$ & $16.6 \pm 33.1(9)$ \\
Relocated nests & $69.2 \pm 21.1(4)$ & $36.0 \pm 17.2(10)$ & $47.3 \pm 14.6(14)$ & $11.6 \pm 21.0(19)$ & $14.5 \pm 12.8(14)$ & $2.1 \pm 4.5(10)$ & $41.9 \pm 32.1(8)$ \\
Hatchery nests & $78.2 \pm 19.7(10)$ & $54.8 \pm 21.4(15)$ & $31.4 \pm 17.0(15)$ & $38.9 \pm 24.0(27)$ & $60.5 \pm 23.7(15)$ & $16.4 \pm 16.6(11)$ & $80.4 \pm 16.7(10)$ \\
$\begin{array}{l}\text { Recommended } \\
\text { strategy }\end{array}$ & Relocation & Hatchery & Natural & Hatchery & Hatchery & Translocation & Hatchery \\
\hline
\end{tabular}

were detected, we used a multiple comparisons Tukey test, to determine which years or sites were different. We performed a $\chi^{2}$ test for given probabilities, to identify any significant differences in flooding and predation between years and sites. We tested if management strategies were significantly different using a Kruskal-Wallis test.

\section{Results}

\section{Numbers and spatial-temporal distribution of nests}

In each year we recorded the first nests in early June, and the nesting season continued until early November, with peak nesting activity in August (Fig. 2). We observed a total of 10,985 nesting activities (clutches laid and aborted nesting attempts) in 2016, 12,806 in 2017, 30,075 in 2018 and 19,316 in 2019, corresponding to a minimum of 4,063, 5,429, 14,364 and 7,937 clutches, respectively (Table 1 ). The eastern coast of
Maio (sites 2, 3 and 4; Fig. 1) had the highest number and density of nests every year (1,281-2,113 nests/km; Table 1$)$ and the north-west had the lowest density (49-151 nests/km; Table 1).

On the island of Boa Vista in Cabo Verde, females produce 3-5 clutches per season (Varo-Cruz, 2010). Based on this, there could have been $813-4,788$ nesting females per year throughout Maio during the study period. Assuming a mean of four clutches per female and season, we estimate there were $1,016,1,357,3,591$ and 1,984 nesting females during the four years of study, respectively.

\section{Reproductive success}

Nesting success varied between years, being lowest (37.0\%) in 2016 and highest $(47.8 \%)$ in 2018 ( $\mathrm{P}>0.05)$. It also varied between sites, being consistently lowest (20.2-30.8\%) at site 5 and highest $(48.1-65.0 \%)$ at site 2 (ANOVA $\mathrm{df}=8$, 


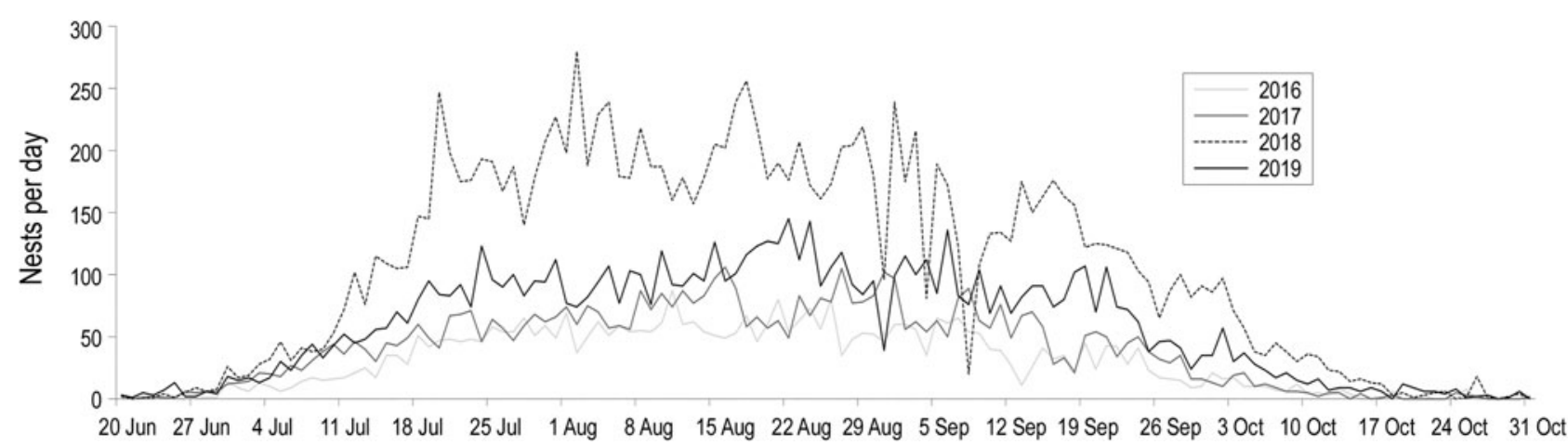

FIG. 2 Temporal pattern of loggerhead turtle nesting on Maio, Cabo Verde.

$\mathrm{F}=13.53, \mathrm{P}<0.0001$; Table 2). Hatching success was significantly different between sites but not between years (two-way ANOVA site: year $\mathrm{df}=6, \mathrm{~F}=3.34, \mathrm{P}<0.001$ ). Hatching success was lowest (minimum $4.4 \%$ ) at sites 5 and 7 , and highest (maximum 59.9\%) at sites 2 and 3, which had the highest abundance and density of nests (Table 2 ).

Nest flooding varied between years $\left(\chi^{2}=11.07, \mathrm{df}=1\right.$, $\mathrm{P}<0.001$ ) and sites, from $8.3 \%$ of nests flooded at site 2 in 2017 to $92.5 \%$ at site 3 in $2018\left(\chi^{2}=43.71, \mathrm{df}=6\right.$, $\mathrm{P}<0.0001$; Table 2). Nest poaching was confirmed at two sites in 2017 and at three sites in 2018; an estimated $1.7 \%$ ( $\mathrm{n}=171$ in 2017) and $1.5 \%(\mathrm{n}=178$ in 2018) of clutches were illegally harvested. Natural predation, mainly by ghost crabs Ocypode sp. (Marco et al., 2015; Rodrigues et al., 2016) was stable between years for the entire island (from $40.2 \%$ in 2018 to $42.2 \%$ in 2017; $\mathrm{P}>0.05)$, but varied between beaches $\left(\chi^{2}=49.69\right.$, $\mathrm{df}=6, \mathrm{P}<0.0001)$. Nest predation by domestic dogs was documented for the first time on the island, at site 7 , near the city of Porto Inglês (Fig. 1), the largest settlement on the island. Of all nests there, $68.4 \%$ were partially or totally affected.

\section{Nest management strategies}

Hatching success was significantly higher in hatcheries compared to natural or relocated nests, considering site and year as random variables (mixed effect model $F=136.74, \mathrm{P}<0.0001$ ). The expected productivity of hatchlings increased in hatcheries: 395,693 hatchlings in hatcheries vs 201,492 hatchlings in control nests. Relocated nests (2018, site 1; Fig. 1) had a slightly higher hatching success than in situ control nests (70\% relocated vs $56 \%$ control; $\mathrm{P}>0.05)$ and hatchling productivity was 51,535 hatchlings in relocated nests vs 41,653 in control nests. Hatching success for nests moved to a hatchery on a different beach (from site 6; Fig. 1, Table 3) was also significantly higher than that of control nests (88\% translocated vs $39 \%$ control; Kruskal-Wallis test $\chi^{2}=16,533, \mathrm{df}=1, \mathrm{P}<0.0001$ ) and hatchling productivity was 81,648 hatchlings in translocated nests vs 36,136 in control nests.

\section{Discussion}

\section{Importance of Maio for nesting loggerhead turtles}

This is the first multi-year quantitative report on the nesting activity of loggerhead turtles on Maio Island, Cabo Verde. Our findings demonstrate that the nesting colony is considerably larger than previously estimated (Cozens et al., 2011; Dutra \& Koenen, 2014). In 2018, there were c. 15,000 nests on Maio, which is $7.5 \%$ of the estimated global total of 200,000 nests/year (Casale \& Tucker, 2017). Our counts on Maio and data from other locations (Broderick et al., 2002; Marcovaldi \& Chaloupka, 2007; Zbinden et al., 2007; Durmus et al., 2011; Casale \& Tucker, 2017; Laloë et al., 2019) indicate Maio is among the five largest loggerhead nesting colonies globally (Table 4), making it an important site for loggerhead conservation both regionally and globally (Wallace et al., 2010, 2011; Mazaris et al., 2017).

\section{Nest mortality and management strategies}

The most prevalent threats to the nests on Maio were tidal flooding, beach erosion and predation by crabs. Near the city of Porto Inglês, predation by dogs is an emerging problem that needs to be addressed. Poaching was not a major threat on Maio, probably as a result of ongoing conservation efforts. The eastern coast hosts the largest number of nests at the highest density, with the highest nesting success and consequently the greatest number of hatchlings. This could be positively reinforced over time if nesting philopatry is restricted to the beach or area where hatchlings emerged. In situ nesting success varied between beaches. Females nested more frequently on the beaches with higher hatching success (sites 2 and 5 ; Table 1 ). This could confer an adaptive advantage if the females' preferred microhabitats increase the chances of survival for their offspring (Marco et al., 2018a; Patrício et al., 2018).

Environmental conditions and mortality rates vary between areas. To increase hatchling productivity, different nest management strategies are thus required, depending on 
TABLE 4 Loggerhead sea turtle nesting on Maio Island compared to major subpopulations around the world.

\begin{tabular}{|c|c|c|c|}
\hline $\begin{array}{l}\text { Subpopulation } \\
\text { (Regional } \\
\text { Management } \\
\text { Unit) }\end{array}$ & $\begin{array}{l}\text { Abundance } \\
\text { (nests/year) }\end{array}$ & $\begin{array}{l}\% \text { of estimated } \\
\text { global nests } \\
(200,000 / \text { year })\end{array}$ & Source \\
\hline $\begin{array}{c}\text { North West } \\
\text { Atlantic }\end{array}$ & 83,717 & 41.8 & $\begin{array}{l}\text { Casale \& Tucker } \\
\text { (2017) }\end{array}$ \\
\hline $\begin{array}{l}\text { North West } \\
\text { Indian }\end{array}$ & 70,000 & 35.0 & $\begin{array}{l}\text { Casale \& Tucker } \\
\text { (2017) }\end{array}$ \\
\hline $\begin{array}{l}\text { North East } \\
\text { Atlantic }^{1}\end{array}$ & 15,000 & 7.5 & $\begin{array}{l}\text { Casale \& Tucker } \\
\text { (2017) }\end{array}$ \\
\hline North Pacific & 9,053 & 4.5 & $\begin{array}{l}\text { Casale \& Tucker } \\
\text { (2017) }\end{array}$ \\
\hline $\begin{array}{l}\text { Maio Island } \\
\qquad(2016-2019)^{1}\end{array}$ & 7,949 & 4.0 & This study \\
\hline $\begin{array}{c}\text { South West } \\
\text { Atlantic }\end{array}$ & 7,696 & 3.8 & $\begin{array}{l}\text { Laloë et al. } \\
\text { (2019) }\end{array}$ \\
\hline Mediterranean & 7,200 & 3.6 & $\begin{array}{l}\text { Casale \& Tucker } \\
\text { (2017) }\end{array}$ \\
\hline $\begin{array}{l}\text { South West } \\
\text { Indian }\end{array}$ & 4,600 & 2.3 & $\begin{array}{l}\text { Casale \& Tucker } \\
\text { (2017) }\end{array}$ \\
\hline $\begin{array}{l}\text { South East } \\
\text { Indian }\end{array}$ & 2,955 & 1.5 & $\begin{array}{l}\text { Casale \& Tucker } \\
\text { (2017) }\end{array}$ \\
\hline
\end{tabular}

${ }^{1}$ Data from Cabo Verde, subpopulation of the North East Atlantic Regional Management Unit.

the local context. On Maio, the productivity of hatchlings from nests in suboptimal areas could be increased by up to 2.3 times by translocating clutches to protected beaches with more favourable conditions. Hatchling productivity doubled for clutches moved to hatcheries on the same beach where they were laid. At sites with high natural hatching success, we recommend relocating clutches to areas beyond the flood line on the same beach (without hatcheries) or leaving the nests in situ. Although we found hatcheries to be successful, they also require greater financial investment and effort, and are therefore not always the best management option (Sieg et al., 2011; van de Merwe et al., 2013). Use of hatcheries for conservation purposes should be considered only as a last resort if the population is threatened, there is high nest mortality and nests cannot be managed in situ (Patino-Martinez et al., 2012). In addition, sand temperature should be recorded in hatcheries and more widely on nesting beaches, to generate robust estimates of primary sex ratios, a global research priority for sea turtles (Hamann et al., 2010).

\section{Conservation on Maio}

The island of Maio has pristine beaches without light pollution, extensive coastal infrastructure or mass tourism, and with high numbers and densities of loggerhead turtle nests. Given that coastlines globally are becoming increasingly urbanized, illuminated and disturbed (Godoy \&
Stockin, 2018; Windle et al., 2018; Blackburn et al., 2019; Winger et al., 2019), and that sea turtles are considered conservation-dependent (Godfrey \& Godley, 2008), undisturbed rookeries such as Maio are important refuges for conservation. The protection of these unique habitats must be prioritized to conserve coastal biodiversity (Antworth et al., 2006). Conditions on Maio could deteriorate if, as has been the case on other islands in Cabo Verde, tourism and related infrastructure are developed along the coast.

For Maio, the main conservation objectives are to maintain the natural conditions of the coastal ecosystem, to train and involve local people in the sustainable management of their natural resources, and to improve peoples' wellbeing through social investment. Sea turtle nesting beaches in other Cabo Verdean islands (Silva et al., 2017; Laloë et al., 2019) and beyond (Godoy \& Stockin, 2018; Blackburn et al., 2019; Colman et al., 2020) are increasingly urbanized, illuminated and exploited for tourism. Any future development on Maio will need to consider our findings, and decisions should be based on a multi-criteria decision analysis for nature conservation (Esmail \& Geneletti, 2018).

\section{Importance of Cabo Verde}

Our observations on Maio during 2016-2019 and the increase in nesting activity in Cabo Verde since 2015 (Marco et al., 2018b; Laloë et al., 2019), highlight the importance of the Cabo Verde subpopulation for loggerhead turtle conservation. The annual number of loggerhead turtle nests on Sal Island (Laloë et al., 2019) is similar to that of Maio. Approximately $75 \%$ of nesting in Cabo Verde occurs on the island of Boa Vista (Marco et al., 2012, 2015; Tanner et al., 2019), Maio and Sal islands host $16.6 \%$ of nests (Laloë et al., 2019) and the remainder are deposited on the other islands (Ministério da Agricultura e Ambiente, Direçao Nacional do Ambiente, unpubl. data). We thus estimate there have been a mean of $95,762 \pm$ SD 55,038 nests annually in Cabo Verde during 2016-2019, which may be the largest loggerhead turtle nesting population globally (Florida, western North Atlantic: 83,717 nests/ year, Oman: 70,000 nests/year; Casale \& Tucker, 2017). The species may be increasing in abundance in part of its range and decreasing elsewhere (Wallace et al., 2010). There has been evidence of a decline in the number of loggerhead turtle nests in Oman during 1978-2016 (55,202 nests/year), possibly because of a decreasing number of females (Willson et al., 2020), and the 30-year pattern (19892018) of the population in Florida portrayed a general nonmonotonic trend with wide fluctuations (Ceriani et al., 2019; Witherington et al., 2009). To compare population trends and assess the overall status of the species (Richards et al., 2011; Mazaris et al., 2017), it is necessary to accurately estimate both the number of nests and the reproductive 
parameters that allow the number of adult females to be calculated (Esteban et al., 2017; Ceriani et al., 2019). In Cabo Verde, further studies are required to examine whether nesting activity was unusually high during 2016-2019, or whether our data reflect the normal pattern for this population.

The island of Maio is a globally important refuge for loggerhead turtle reproduction. Its coastal habitats are largely undisturbed, and other species of sea turtle, or taxa belonging to so-called dark diversity (Lewis et al., 2017), may be present. However, there is pressure for economic growth from its inhabitants. The authorities have initiated the expansion of the island's port and plan to build additional tourist accommodation, which could result in an increase in the number of inhabitants and associated pollution. In this scenario, conservation problems involve socio-cultural, economic, and spatially explicit factors. Natural science alone is insufficient to find solutions to complex conservation problems that have social dimensions (Sandbrook et al., 2013) and therefore, appropriate methods of stakeholder engagement and synthesis of their knowledge and interests are needed (Pullin et al., 2016). Communities must take ownership of the management and conservation of their natural resources (Rees et al., 2016; Patino-Martinez et al., 2020) and benefit from the economic investment derived from conservation projects.

Acknowledgements We thank local rangers, team leaders, supervisors and volunteers for their help with data collection; the Cabo Verde national environmental authority, Direção Nacional do Ambiente, for authorizing the study; MAVA Fondation pour la Nature, the National Oceanic and Atmospheric Administration and the U.S. Fish \& Wildlife Service for funding; Gemma Charles, Lucy Hawkes, Graeme Hays and an anonymous reviewer for their help in improving the manuscript.

Author contributions Conceptualization: JP-M, LDP, AT, MT; methodology: JP-M, LDP; data analysis: JP-M, IOA, TS; visualization: JP-M, IOA, MT, TS, RM; supervision: JP-M; project administration: JP-M, LDP, RM; resources: LDP, AT, MT, TS; funding acquisition: LDP, AT, MT; writing: JP-M; revisions: IOA, MT, TS, RM.

\section{Conflicts of interest None.}

Ethical standards This research abided by the Oryx guidelines on ethical standards. It did not involve human subjects and/or collection of specimens. The research followed protocols recommended by Stokes et al. (2008). The national environmental authority Direção Nacional do Ambiente provided permits for this research.

\section{References}

Abella Perez, E., Marco, A., Martins, S. \& Hawkes, L.A. (2016) Is this what a climate change-resilient population of marine turtles looks like? Biological Conservation, 193, 124-132.

Antworth, R.L., Pike, D.A. \& Stiner, J.C. (2006) Nesting ecology, current status, and conservation of sea turtles on an uninhabited beach in Florida, USA. Biological Conservation, 130, 10-15.
Baldwin, R., Hughes, G.R. \& Prince, R.I.T. (2003) Loggerhead turtles in the Indian ocean. In Loggerhead Sea Turtles (eds A.B. Bolten \& B.E. Witherington), pp. 218-232. Smithsonian Books, Washington, DC, USA.

Bielli, A., Alfaro-Shigueto, J., Doherty, P., Godley, B., Ortiz, C., Pasara, A. et al. (2019) An illuminating idea to reduce bycatch in the Peruvian small-scale gillnet fishery. Biological Conservation, 241, 108277.

Blackburn, S., Pelling, M. \& Marques, C. (2019) Megacities and the coast: global context and scope for transformation. In Coasts and Estuaries: The Future (eds E. Wolanski, J.D. Day, M. Elliot \& R. Ramachandran), pp. 661-669. Elsevier, Amsterdam, The Netherlands.

Broderick, A.C., Glen, F., Godley, B.J. \& Hays, G.C. (2002) Estimating the number of green and loggerhead turtles nesting annually in the Mediterranean. Oryx, 36, 227-235.

Camacho, M., Boada, L.D., Oros, J., Lopez, P., Zumbado, M., Almeida-Gonzalez, M. \& Luzardo, O.P. (2013) Comparative study of organohalogen contamination between two populations of Eastern Atlantic loggerhead sea turtles (Caretta caretta). Bulletin of Environmental Contamination and Toxicology, 91, 678-683.

CAsale, P. (2015) Caretta caretta (North West Indian Ocean subpopulation). In The IUCN Red List of Threatened Species 2015. dx.doi.org/10.2305/IUCN.UK.2015-4.RLTS.T84127873A84127992.en [accessed 24 January 2020].

Casale, P. \& Marco, A. (2015) Caretta caretta (North East Atlantic subpopulation). In The IUCN Red List of Threatened Species 2015. dx.doi.org/10.2305/IUCN.UK.2015-4.RLTS.T83776383A83776554.en [accessed 24 January 2020].

Casale, P. \& Matsuzawa, Y. (2015) Caretta caretta (North Pacific subpopulation). In The IUCN Red List of Threatened Species 2015. dx.doi.org/10.2305/IUCN.UK.2015-4.RLTS.T83652278A83652322.en [accessed 24 January 2020].

Casale, P. \& Tucker, A.D. (2017) Caretta caretta (amended version of 2015 assessment). In The IUCN Red List of Threatened Species 2017. dx.doi.org/10.2305/IUCN.UK.2017-2.RLTS.T3897A119333622.en [accessed 25 August 2020].

Ceriani, S., Casale, P., Brost, M., Leone, E. \& Witherington, B. (2019) Conservation implications of sea turtle nesting trends: elusive recovery of a globally important loggerhead population. Ecosphere, 10, 002936 .

Coelho, R., Santos, M.N., Fernandez-Carvalho, J. \& Amorim, S. (2015) Effects of hook and bait in a tropical northeast Atlantic pelagic longline fishery: part I-incidental sea turtle bycatch. Fisheries Research, 164, 302-311.

Colman, L.P., Lara, P.H., Bennie, J., Broderick, A.C., De Freitas, J.R., Marcondes, A. et al. (2020) Assessing coastal artificial light and potential exposure of wildlife at a national scale: the case of marine turtles in Brazil. Biodiversity and Conservation, 29, 1135-1152. Cornwell, M.L. \& CAM PBelL, L.M. (2012) Co-producing conservation and knowledge: citizen-based sea turtle monitoring in North Carolina, USA. Social Studies of Science, 42, 101-120.

Cozens, J., Taylor, H. \& Gouveia, J. (2011) Nesting activity of the loggerhead sea turtle Caretta caretta (Linnaeus, 1758) on Maio, Cape Verde Islands. Zoologia Caboverdiana, 2, 62-70.

Durmus, S.H., Ilgaz, C., Ozdemir, A. \& Yerli, S.V. (2011) Nesting activity of loggerhead turtles (Caretta caretta) at Goksu Delta, Turkey during 2004 and 2008 nesting seasons. Ecologia Balkanica, 3, 95-106.

Dutra, A. \& Koenen, F. (2014) Community-based conservation: the key to protection of marine turtles on Maio Island, Cape Verde. Oryx, 48, 325-325.

Ehrhart, L.M., Bagley, D.A. \& Redfoot, W.E. (2003) Loggerhead turtles in the Atlantic Ocean: geographic distribution, abundance 
and population status. In Loggerhead Sea Turtles (eds A.B. Bolten \& B.E. Witherington), pp. 155-174. Smithsonian Books, Washington, DC, USA.

Esmail, B.A. \& Geneletti, D. (2018) Multi-criteria decision analysis for nature conservation: a review of 20 years of applications. Methods in Ecology and Evolution, 9, 42-53.

Esteban, N., Mortimer, J.A. \& Hays, G.C. (2017) How numbers of nesting sea turtles can be overestimated by nearly a factor of two. Proceedings of the Royal Society B, 284, 20162581.

Godfrey, M.H. \& Godley, B.J. (2008) As we see it: seeing past the red: flawed IUCN global listings for sea turtles. Endangered Species Research, 6, 155-159.

Godley, B., Broderick, A., Colman, L., Formia, A., Godfrey, M., Hamann, M. et al. (2020) Reflections on sea turtle conservation. Oryx, 54, 287-289.

Godoy, D.A. \& Stockin, K.A. (2018) Anthropogenic impacts on green turtles Chelonia mydas in New Zealand. Endangered Species Research, 37, 1-9.

Hamann, M., Godfrey, M.H., Seminoff, J.A., Arthur, K., Barata, P.C.R., BJORNDAL, K.A. et al. (2010) Global research priorities for sea turtles: informing management and conservation in the 21st century. Endangered Species Research, 11, 245-269.

Hancock, J.M., Furtado, S., Merino, S., Godley, B.J. \& Nuno, A. (2017) Exploring drivers and deterrents of the illegal consumption and trade of marine turtle products in Cape Verde, and implications for conservation planning. Oryx, 51, 428-436.

Hawkes, L.A., Broderick, A.C., Coyne, M.S., Godfrey, M.H., LopeZ-Jurado, L.F., Lopez-SuAreZ, P. et al. (2006)

Phenotypically linked dichotomy in sea turtle foraging requires multiple conservation approaches. Current Biology, 16, 990-995.

Hays, G.C., Bailey, H., Bograd, S.J., Bowen, W.D., Campagna, C., CARMICHAEL, R.H. et al. (2019) Translating marine animal tracking data into conservation policy and management. Trends in Ecology \& Evolution, 34, 459-473.

Laloë, J.-O., Cozens, J., Renom, B., Taxonera, A. \& Hays, G.C. (2019) Conservation importance of previously undescribed abundance trends: increase in loggerhead turtle numbers nesting on an Atlantic island. Oryx, 54, 315-322.

Lewis, R., de Bello, F., Bennett, J.A., Fibich, P., Finerty, G.E., Götzenberger, L. et al. (2017) Applying the dark diversity concept to nature conservation. Conservation Biology, 31, 40-47.

Lewison, R.L., Crowder, L.B., W allace, B.P., Moore, J.E., Cox, T., Zydelis, R. et al. (2014) Global patterns of marine mammal, seabird, and sea turtle bycatch reveal taxa-specific and cumulative megafauna hotspots. Proceedings of the National Academy of Sciences of the United States of America, 111, 5271-5276.

Lopes, K., PAssos, L., Rodrigues, J.G., Koenen, F., Stiebens, V., Székely, T. \& Dutra, A. (2016) Sea turtle, shark, and dolphin bycatch rates by artisanal and semi-industrial fishers in Maio Island, Cape Verde. Chelonian Conservation and Biology, 15, 279-288.

López-Jurado, L., Varo-Cruz, N. \& López-Suárez, P. (2003) Incidental capture of loggerhead turtles (Caretta caretta) on Boa Vista (Cape Verde Islands). Marine Turtle Newsletter, 101, 14-16.

Loureiro, N.S. (2008) Sea turtles in Santiago Island, Cape Verde. Marine Turtle Newsletter, 120, 6-8.

Marco, A., Abella, E., Liria-Loza, A., Martins, S., Lopez, O., JimenEZ-Bordon, S. et al. (2012) Abundance and exploitation of loggerhead turtles nesting in Boa Vista island, Cape Verde: the only substantial rookery in the eastern Atlantic. Animal Conservation, $15,351-360$.

Marco, A., Da Graça, J., García-Cerdá, R., Abella, E. \& Freitas, R. (2015) Patterns and intensity of ghost crab predation on the nests of an important endangered loggerhead turtle population. Journal of Experimental Marine Biology and Ecology, 468, 74-82.
Marco, A., Abella, E., Martins, S., López, O. \& PatinoMartinez, J. (2018a) Female nesting behaviour affects hatchling survival and sex ratio in the loggerhead sea turtle: implications for conservation programmes. Ethology Ecology \& Evolution, 30, 141-155.

Marco, A., Tavares Martins, S., Abella, E. \& PatinoMartinez, J. (2018b) Potential causes for an important and hopeful increase in sea turtle nesting in Cabo Verde in 2018. African Sea Turtle Newsletter, 10, 1-6.

Marcovaldi, M.Â. \& CHAloupKa, M. (2007) Conservation status of the loggerhead sea turtle in Brazil: an encouraging outlook.

Endangered Species Research, 3, 133-143.

Maxwell, S.M., Broderick, A.C., Dutton, P.H., Fossette-Halot, S., Fuentes, M.M. \& Reina, R.D. (2019) Advances in the biology and conservation of marine turtles. Frontiers in Marine Science, 6, 9.

Mazaris, A.D., Schofield, G., Gkazinou, C., Almpanidou, V. \& HAYs, G.C. (2017) Global sea turtle conservation successes. Science Advances, 3, e160o73o.

McClenachan, L., Jackson, J.B.C. \& Newman, M.J.H. (2006) Conservation implications of historic sea turtle nesting beach loss. Frontiers in Ecology and the Environment, 4, 290-296.

Monzon-Arguello, C., Rico, C., Naro-Maciel, E., Varo-Cruz, N., Lopez, P., Marco, A. \& Felipe Lopez-Jurado, L. (2010) Population structure and conservation implications for the loggerhead sea turtle of the Cape Verde Islands. Conservation Genetics, 11, 1871-1884.

Nordberg, E.J., Macdonald, S., Zimny, G., Hoskins, A., Zimny, A., Somaweera, R. et al. (2019) An evaluation of nest predator impacts and the efficacy of plastic meshing on marine turtle nests on the western Cape York Peninsula, Australia. Biological Conservation, 238, 108201.

Patino-Martinez, J., Marco, A., Quinones, L. \& Hawkes, L. (2012) A potential tool to mitigate the impacts of climate change to the Caribbean leatherback sea turtle. Global Change Biology, $18,401-411$.

Patino-Martinez, J., Godley, B.J., Quiñones, L. \& Marco, A. (2017) Impact of tropical forest logging on the reproductive success of leatherback turtles. Marine Ecology Progress Series, 569, 205-214.

Patino-Martinez, J., Dos Passos, L., Dos Reis, E. \& Moreno, R. (2020) Integrating local leaders in efforts to improve biodiversity conservation. African Sea Turtle Newsletter, 12, 4-7.

Patrício, A.R., Varela, M.R., Barbosa, C., Broderick, A.C., Airaud, M.B.F., Godley, B.J. et al. (2018) Nest site selection repeatability of green turtles, Chelonia mydas, and consequences for offspring. Animal Behaviour, 139, 91-102.

Patrício, A., Varela, M., Barbosa, C., Broderick, A., Catry, P., HAWKes, L. et al. (2019) Climate change resilience of a globally important sea turtle nesting population. Global Change Biology, 25, 522 .

Polasky, S. (2008) Why conservation planning needs socioeconomic data. Proceedings of the National Academy of Sciences of the United States of America, 105, 6505-6506.

Pullin, A., Frampton, G., Jongman, R., Kohl, C., Livoreil, B., Lux, A. et al. (2016) Selecting appropriate methods of knowledge synthesis to inform biodiversity policy. Biodiversity and Conservation, 25, 1285-1300.

R Core Team (2018) R: A Language and Environment for Statistical Computing. R Foundation for Statistical Computing, Vienna, Austria.

Rees, A., Alfaro-Shigueto, J., Barata, P., Bjorndal, K.A., Bolten, A.B., BourjeA, J. et al. (2016) Are we working towards global research priorities for management and conservation of sea turtles? Endangered Species Research, 31, 337-382. 
Richards, P.M., Epperly, S.P., Heppell, S.S., King, R.T., Sasso, C.R., Moncada, F. et al. (2011) Sea turtle population estimates incorporating uncertainty: a new approach applied to western North Atlantic loggerheads Caretta caretta. Endangered Species Research, 15, 151-158.

Rocha, P.R., Melo, T., Rebelo, R. \& Catry, P. (2015) A significant nesting population of loggerhead turtles at the nature reserve of Santa Luzia, Cabo Verde. Chelonian Conservation and Biology, $14,161-166$.

Rodrigues, E., Freitas, R., Delgado, N.D.C. \& Soares-Gomes, A. (2016) Distribution patterns of the ghost crab Ocypode cursor on sandy beaches of a tropical island in the Cabo Verde archipelago, Eastern Central Atlantic. African Journal of Marine Science, $38,181-188$.

SAGE, R. (2020) Global change biology: a primer. Global Change Biology, 26, 3-30.

Sandbrook, C., Adams, W.M., Büscher, B. \& Vira, B. (2013) Social research and biodiversity conservation. Conservation Biology, 27, 1487-1490.

Santos, M.N., Coelho, R., Fernandez-Carvalho, J. \& Amorim, S. (2013) Effects of 17/o circle hooks and bait on sea turtles bycatch in a Southern Atlantic swordfish longline fishery. Aquatic Conservation-Marine and Freshwater Ecosystems, 23, 732-744.

Scott, R., Biastoch, A., Roder, C., Stiebens, V. \& Eizaguirre, C. (2014) Nano-tags for neonates and ocean-mediated swimming behaviours linked to rapid dispersal of hatchling sea turtles. Proceedings of the Royal Society B, 281, 20141209.

Sella, K.A.N. \& Fuentes, M.M. (2019) Exposure of marine turtle nesting grounds to coastal modifications: implications for management. Ocean \& Coastal Management, 169, 182-190.

Sieg, A.E., Binckley, C.A., Wallace, B.P., Santidrian Tomillo, P., Reina, R.D., Paladino, F.V. \& Spotila, J.R. (2011) Sex ratios of leatherback turtles: hatchery translocation decreases metabolic heating and female bias. Endangered Species Research, 15, 195-204.

Silva, E., Marco, A., Da Graça, J., Pérez, H., Abella, E., Patino-Martinez, J. et al. (2017) Light pollution affects nesting behavior of loggerhead turtles and predation risk of nests and hatchlings. Journal of Photochemistry and Photobiology B: Biology, 173, 240-249.

Stiebens, V.A., Merino, S.E., Roder, C., Chain, F.J.J., Lee, P.L.M. \& Eizaguirre, C. (2013) Living on the edge: how philopatry maintains adaptive potential. Proceedings of the Royal Society $B$, 280, 20130305.

Stokes, L., Epperly, S.P., Avens, L.I., Belskis, L.C., Benson, S.R., Braun-McNeill, J. et al. (2008) Sea Turtle Research Techniques Manual. NOAA Technical Memorandum NMFS-SEFSC-579, NOAA Fisheries, Miami, USA.

Tanner, C., Marco, A., Martins, S., Perez, E.A. \& Hawkes, L. (2019) Highly feminised sex ratio estimations for the world's third largest nesting aggregation of the loggerhead sea turtle. Marine Ecology Progress Series, 621, 209-219.
TAylor, H. \& Cozens, J. (2010) The effects of tourism, beachfront development and increased light pollution on nesting loggerhead turtles Caretta caretta (Linnaeus, 1758) on Sal, Cape Verde Islands. Zoologia Caboverdiana, 1, 100-111.

Tilman, D., May, R.M., Lehman, C.L. \& NowaK, M.A. (1994) Habitat destruction and the extinction debt. Nature, 371, 65-66.

Tomas, J., Godley, B.J., Castroviejo, J. \& RaGa, J.A. (2010) Bioko: critically important nesting habitat for sea turtles of West Africa. Biodiversity and Conservation, 19, 2699-2714.

Usategui-Martín, A., Liria-Loza, A., Miller, J.D., Medina-Suárez, M., Jiménez-Bordón, S., Pérez-Mellado, V. \& Montero, D. (2019) Effects of incubation temperature on hatchling performance and phenotype in loggerhead sea turtle Caretta caretta. Endangered Species Research, 38, 45-53.

van de Merwe, J.P., Ibrahim, K. \& Whittier, J.M. (2013) Post-emergence handling of green turtle hatchlings: improving hatchery management worldwide. Animal Conservation, $16,316-323$.

VAro-Cruz, N. (2010) Biología reproductora de la Tortuga Boba (Caretta caretta Linneo, 1758) en la isla de BoaVista, archipiélago de Cabo Verde. PhD thesis, University of Las Palmas de Gran Canaria, Las Palmas, Spain.

Wallace, B.P., DiMatteo, A.D., Hurley, B.J., Finkbeiner, E.M., Bolten, A.B., Chaloupka, M.Y. et al. (2010) Regional management units for marine turtles: a novel framework for prioritizing conservation and research across multiple scales. PLOS ONE, 5, e15465.

Wallace, B.P., DiMatteo, A.D., Bolten, A.B., Chaloupka, M.Y., Hutchinson, B.J., Abreu-Grobois, F.A. et al. (2011) Global conservation priorities for marine turtles. PLOS ONE, 6, e24510.

WAtson, J. \& Venter, O. (2017) ECOLOGY: a global plan for nature conservation. Nature, 550, 48-49.

Willson, A., Witherington, B., Baldwin, R., Timari, M., Al SARIRI, T., Al Kiyumi, A. et al. (2020) Evaluating the long-term trend and management of a globally important loggerhead population nesting on Masirah Island, Sultanate of Oman. Frontiers in Marine Science, 7, 666.

Windle, A.E., Hooley, D.S. \& Johnston, D.W. (2018) Robotic vehicles enable high-resolution light pollution sampling of sea turtle nesting beaches. Frontiers in Marine Science, 5, 493.

Winger, B.M., Weeks, B.C., Farnsworth, A., Jones, A.W., Hennen, M. \& Willard, D.E. (2019) Nocturnal flight-calling behaviour predicts vulnerability to artificial light in migratory birds. Proceedings of the Royal Society B, 286, 20190364.

Witherington, B., Kubilis, P., Brost, B. \& Meylan, A. (2009) Decreasing annual nest counts in a globally important loggerhead sea turtle population. Ecological Applications, 19, 30-54.

Zbinden, J.A., Largiader, A.R., Leippert, F., Margaritoulis, D. \& Arlettaz, R. (2007) High frequency of multiple paternity in the largest rookery of Mediterranean loggerhead sea turtles. Molecular Ecology, 16, 3703-3711. 